\title{
VESPA ARCTICA ROHWER, A PARASITE OF VESPA DIABOLICA DE SAUSSURE. ${ }^{1}$
}

By W. M. Wheeler and L. H. Taylor.

The summer of 1921, at least in New England, was a "wasp summer," probably on account of the protracted, hot, dry weather during June and July. Certain species of Vespa, especially the common yellow-jacket, $V$. diabolica, were unusually abundant. Probably for this reason we were able to make the following observations on a rare wasp, $V$. arctica, which, as shown by Fletcher in a paper read before the Entomological Society of America (1908), is a parasite in the nest of diabolica. Unfortunately, Fletcher died before he could publish his paper, and the very brief notice of it in the proceedings of the Society is all that has appeared.

During the summer of 1921 the senior author spent his vacation at Colebrook, in the Litchfield Hills of Connecticut; the junior author at Forest Hills, near Boston. In both places a number of diabolica nests were examined, and in three of them arctica was taken. The latter species ${ }^{2}$ is black and white, and in size and markings may be very readily mistaken for $V$. consobrina De Saussure, but closer examination shows that it has long cheeks and long hairs on the tibiæ. It lacks, moreover, the worker caste, and therefore differs from all known species of Vespa, except austriaca Panzer, which will be considered more fully in the sequel. This absence of the worker caste at once suggests that arctica is a social parasite like the species of Psithyrus in the nests of bumble-bees and certain ants (Anergates, Epoecus, Epipheidole, Sympheidole, Anergatides, etc.) in the nests of Tetramorium, Monomorium and

\footnotetext{
1 Contributions from the Entomological Laboratory of the Bussey Institution, Harvard University. No. 195.

2 This species was originally described by Lewis (Trans. Amer. Ent. Soc. 24, 1897, p. 173) as Vespa borealls, but Rohwer (in Viereck, Hymenoptera, or Wasp-like Insects of Connecticut, 1916, changed the name to arctica, as Kirby had previously described a V. borealls (Fauna Boreali-Americana, 1837 , p. 264).
} 
Pheidole. $V$. arctica belongs to the Canadian and Upper Transition zones. Sladen (1918) records it as ranging from Nova Scotia to British Columbia. It has been recorded from Amherst, Mass., according to Rohwer (Viereck, 1916), and by him included in the list of Connecticut Hymenoptera as probably occurring in that state. The senior author has taken it repeatedly but sparingly at Colebrook (1200-1600 ft.) during the summers of 1918 and 1919, on the flowers of Spircea salicifolia. Until it was taken by the junior author at Forest Hills during the past summer, there was no record of its occurrence near sea-level and in Eastern Massachusetts.

The three observations that go to confirm Fletcher's contention that arctica is a social parasite in the nests of diabolica are the following:

1. On July 4, the senior author's attention was called to a diabolica nest attached to the bottom of the back-net of his tenniscourt, at the surface of the ground, in a bunch of grass and sensitive fern. As the wasps were intimidating the players, the colony was asphyxiated after dusk on July 7 by throwing cloths saturated with carbon bisulphide over the nest. On removing the cloths on the following morning, the nest and its occupants were carefully examined. The structure had attained the size and shape of an orange about $12 \mathrm{~cm}$. in diameter, and contained two broadly elliptical combs, a larger, upper, measuring 8 by $6.5 \mathrm{~cm}$., and a smaller, lower, measuring 7 by $5 \mathrm{~mm}$. There were 64 wasps in the colony, 62 workers of diabolica, a queen of the same species, and a queen arctica. The upper and older comb had two concentric circles of capped cells, enclosing pupating larvæ and pupæ. The open cells contained eggs and young larvæ of different sizes. Undoubtedly all the brood in this comb represented workers of diabolica. The lower comb (Fig. 1) had a single circle of 20 pupæ of diabolica on half its area, while the center of the other half was occupied by a clearly defined cluster of 11 very large, elongate cells, each containing a conspicuously large larva. These cells are marked with white crosses in the figure. The remaining cells were very small and short and contained eggs and very young larvæ. Evidently all or nearly all the brood, except the 11 large 
larvæ belonged to diabolica. These large larvæ, which were nearly ready to pupate, must have belonged to arctica, and were probably females. That they had been abundantly fed by the diabolica workers and their development favored beyond that of the remaining larvæ was evident from a glance at the two combs. Examination of the two queens, which were of the same size, showed that their wings were mutilated. The apical halves of both wings of the arctica queen on the right side had been bitten off. As both queens were still fresh when found in the nest on the morning of July 8 (the diabolica queen, when stimulated, still moved her tarsi!) we may infer that both were living together in the nest, though probably not on the best of terms, that the arctica queen had probably entered the nest just as the workers were beginning to build the second comb and had oviposited in 11 of its cells, and that the resulting larvæ were being actively fed by the diabolica workers. because the parasite's wings were too much mutilated to permit her to leave the nest and forage.

2. On June 29, the junior author killed a colony of diabolica which had its nest in the hay-scales of the State Antitoxin Laboratory on the grounds of the Bussey Institution. It was younger than the preceding, had one comb and only a few cells of a second, and contained only a small number of diabolica workers and an arctica queen. Since the colony was captured during the day, most of the diabolica workers were probably out foraging, and the absence of the diabolica queen may, perhaps, be accounted for on the same supposition.

3. August 4, the junior author took in the Arnold Arboretum a nest of diabolica containing three recently emerged males of arctica. In the same nest were about a dozen large larvæ and two or three pupæ, evidently queens, though whether of diabolica or arctica was not determined, as they were unpigmented. In all probability, however, they belonged to arctica. The presence of worker larvæ and pupæ indicated that the queens of both species were in the colony at about the same time (that is, if the time for development of diabolica workers is about the same as that required for the arctica males), and that at least one of the queens hard been in the nest very recently was indicated by the numerous eggs, although these might, of course, have been laid by the workers. 
During the entire summer we sought carefully for additional nests of diabolica infested with arctica, but none was found. At Colebrook the males of arctica were not uncommon on the flowers of Spricea salicifolia and Pastinaca sativa, usually during the morning or late afternoon hours in three different localities where infested colonies of diabolica must have been present but could not be located. The first of these males was captured as early as July 16, and a few were taken every few days throughout the remainder of July and the first two weeks of August. Thereafter the species seemed to have disappeared, though in previous years a few males and females were captured as late as September 1. No males of $V$. consobrina were seen on flowers till July 31, and virgin females and males of diabolica did not appear till later (August 20 to 22), and soon afterwards disappeared. It would seem, therefore, that the early emergence and long flying period of the arctica males is an adaptation to insuring the fecundation of the much less numerous females, an adaptation the more necessary because the species is very rare most summers, when the host species, too, is less abundant.

The foregoing observations have an important bearing on what has been learned concerning $V$. austriaca. This wasp, which also lacks a worker caste, has long been known in Europe, where it ranges from Ireland to Russia, with a marked preference for mountains up to an altitude of 5500 feet. It seems also to occur in Palearctic Asia. Recently Bequaert (1916) took two females of austriaca at Fort Lee, New Jersey, opposite New York City, and recorded a specimen taken by Prof. J. S. Hine on the same day (July 16) on Staten Island. More recently (1918) Sladen has taken austriaca at Ottawa and Chelsea, Quebec (mid-June), and at Winnipeg and Kaslo, British Columbia (mid-July), and Bequaert (1920), cites specimens from Savonoski, Alaska (July), Mt. Hood, Oregon (G. P. Engelhardt Coll.), and Beaver Mouth, Selkirk Mountains, British Columbia (J. C. Bradley Coll.). In Europe this wasp has been taken in the nests of $V$. rufa and has been regarded as a parasite of the latter by Morawitz (1864), Schmiedeknecht (1881), Robson (1898), Saunders (1903), Sharp (1893), Pérez (1910), and Bequaert. Carpented and Pack-Beresford (1903) have published a careful account of an austriaca-rufa 
colony taken in Ireland. They show that the two species are very closely related taxonomically, and" infer that "the old austriaca queen was the foundress of the nest and that both the rufa and austriaca are her offspring." The evidence with which they endeavor to support this inference seems to us to be very inconclusive. It is indeed surprising that such accomplished entomologists should have failed to take account of the habits of other parasitic Aculeata, such as Psothyrus and the workerless ants, which are all so much better known than the wasps they werestudying.

The occurrence of austriaca in the vicinity of New York City and in British America and Alaska, at once raises the question as to its American host, since rufa is not known to occur on this side of the Atlantic. Bequaert surmises that consobrina may be the American host, and maintains that this wasp, "although very different in coloration, is very probably the American rase or subspecies of Vespa rufa L." If this proves to be the case, we should have the short-cheeked, black and yellow austriaca living with the short-cheeked, blach and white consobrina, just as our long-cheeked, black and white arctica lives with the long-cheeked, black and yellow diabolica.

The dates of flight of male and female austriaca and rufa, care. fully recorded by British entomologists (Carpenter and Pack-Beresford and Evans (1903)), indicate that the austriaca queens issue from hibernation later in the spring than the nest-founding ruja queens. The same is probably also true of arctica as compared with diabolica. Hence the parasitic queens, when they first appear in the spring, find the host nests already well-established and containing a worker personnel ready to nurse the parasitic brood. The parasitic Psithyri show the same tendency to enter the Bombus colonies only after their first batch of workers has emerged (Sladen, 1912), and the parasitic ants take a similar advantage of their host species.

The presence of both host and parasitic queens in the arcticadiabolica nest examined by the senior author at Colebrook, raises the question as to the probable eventual fate of the host queen in infested nests. In the various cases of the mixed colonies among ants the host queen is soon eliminated, and, according to Sladen (1912), the same rule applies to the Bombus queens of colonies 
invaded by Psithyrus and to the queen of $B$. terrestris lucorum. when its nest is invaded by the queen of $B$. terrestris virginalis. ${ }^{1}$ Had the Colebrook arctica-diabolica colony, which was still young when asphyxiated, been permitted to continue its growth and development, the diabolica queen might, of course, have been eliminated. This would, indeed, seem probable, if we may judge from the observations of Robson and Carpenter and Pack-Beresford on austriaca-rufa colonies, which were well-developed when examined. The colony observed by Robson had no rufa queen, but must have been founded by one, since typical rufa males were present. $\mathrm{He}$ saw the rufa workers dragging out of the nest the decapitated and mutilated carcass of an austriaca queen, presumably after her brood had been reared by the rufa workers. Thus it would seem that in this colony the host-queen had been killed either by her own workers or by the parasitic queen, and that the latter had been killed by the rufa workers or had died a natural death in the nest after completing her life-work. Carpenter and Pack-Beresford give a detailed census of their austriaca-rufa colony. It contained an old austriaca but no rufa queen, besides many males and three pupal queens of austriaca. In this case also, the host queen seems to have been eliminated earlier in the season.

The absence of the host-queen from nests infested by the parasitic wasps, as in the nests of austriaca-rufa just considered and the two arctica-diabolica nests found by the junior author, may be due, nevertheless, to quite other causes. Desertion of the nest by its foundress, even after brood is present, or her destruction while foraging, may leave the colony motherless and open to invasion by parasitic queens. Janet (1903) has even observel the invasion of a motherless $V$. crabro nest by a strange crabro queen, and her adoption by the workers. Both Janet and Marchal (1896) have failed to find the queen in several nests of this wasp, and the latter shows that in the case of $V$. media the queen is so short-lived that she completes oviposition by the beginning of August and disappears soon afterwards. The development of media colonies is, therefore, considerably accelerated as compared with the colonies

\footnotetext{
1 This rule does not seem to apply to some of our American PsithyrusBombus colonies, to judge from the very interesting, unpublished observations made by Mr. O. E. Plath at the Bussey Institution during the past summer.
} 
of $V$.germanica and communis, in which the mother queen is often found as late as the last of September or early October.

Perhaps the diabolica queen may resemble the crabro queen in her tendency to desert an incipient nest and found another, or perhaps, as a rule, she may desert her nest as soon as it is invaded by an arctica queen. That she is short-lived, like the queen of media, seems to be indicated by the following observations on uninfested nests:

July 21, the senior author asphyxiated a diabolica colony which was nesting very near the ground at the base of a cluster of goldenrods in a deserted pasture. The nest was well-developed, with two large combs and a very small, four-celled third comb. There were 76 workers but no queen, although her presence might have been expected, since the colony was asphyxiated after dark.

August $2 \%$, the senior author found depending from the ceiling of ' a porch a small abandoned diabolica nest. It had only a single small comb, about $3.5 \mathrm{~cm}$. in diameter, containing some dead worker pupæ and small larvæ. A similar deserted nest was found earlier in the season attached to the limb of a tree.

Also on August 27 a large, well-developed diabolica nest was found under the roof of a water-tank. Two living workers were still clinging to the involucre, which contained three well-developed combs. There were a few living worker pupæ in the combs and a number of dead workers that had fallen from the nest. The males and virgin females had departed, so that the colony must have completed its development several days and possibly a few weeks before the first of September.

Of eight diabolica nests taken by the junior author before August 4, on the grounds of the Arnold Arboretum, only one contained an old queen, although in each case care was taken to secure the entire colony.

A flourishing colony of $V$. diabolica comprising 200 to 250 workers, also without a queen, was taken August 10. The apparently exclusive emergence of males from this colony, as a result of which there were scarcely 25 workers left in the nest by Sep- 
tember 10, suggested that the queen might have been absent for some time before the earlier date. ${ }^{1}$

Of two diabolica nests taken September 14, one contained approximately 150 workers and 250 males, though the colony must have numbered fully a thousand during its prime. This nest had no queen, but in the other one killed the same day, along with 40 workers and 60 males, was a single virgin female, the last of a considerable number that the colony had produced.

Our observations on $V$. arctica and diabolica, though fragmentary, seem to justify the following conclusions:

1. The nest-founding queen of $V$. diabolica, like that of the European media, is rather short-lived, completing oviposition and perishing rather early in the season, probably not later than the middle or early part of August, at least during favorable summers.

2. There are some indications that the diabolica queen, liks the crabro queen, has a tendency to desert her nest in an incipient stage and found another.

3. V. arctica is a permanent social parasite in the nest of diabotica, and her brood, consisting exclusively of males and fertile females, is reared by the diabolica workers.

4. The over-wintering queen of arctica, like that of austriaca, probably appears late in spring, at a time when the nests of the host-species are already established and contain enough workers to nurse her brood.

1 In taking this nest at dusk the junior author failed to capture about a dozen workers which were still flying about, and which finally settled on the tree from which the nest had been cut. Deprived of their habitation, and even of the branch which supported it, these few workers were huddled together the next evening at a place remote from the original position of the nest. Closer observation revealed that they had already attached bits of newly-made paper to the bark of the tree. It was about this paper that the workers were congregated. By the end of the second day the wasps had suspended a single cell from a strong filament of paper after the manner of a queen in founding her nest in the spring, and in a few more days the structure had begun to assume the proportions of a normal nest. On September 10 it was about the size of a hen's egg and there were still two or three workers defending it (Fig. 3). Six days later this nest was found torn open, apparently by a predator, perhaps a bird, which had robbed it of whatever it might have contained, thereby preventing further observation.

The construction of nests by workers of European species of wasps has been observed by several authors, notably Janet (1903), who describes three new nests built successively by workers of the same colony. Other accounts are given by Ormerod (1859), Stone (1860), von Siebold (1871), Kristof (1878) and Marchal (1896). 
5. The fate of the host queen in such nests is unknown. Whether she voluntarily deserts the nest soon after the parasite enters or is killed by the latter or by her own workers, or whether the parasitic queen has a tendency to enter young motherless nests of the host species, remains to be determind. That both queens may occasionally live side by side for some time, would seem to be demonstrated by the colony examined by the senior author.

6. From what is known of $V$. arctica and austriaca we may conclude that these workerless wasps have essentially the same relations to their host-colonies as the parasitic Psithyri and workerless ants (Anergates, etc.).

\section{BIBLIOGRAPHY.}

1916. Bequaert, $J$. On the Occurrence of Vespa austriaca Panzer in the Northeastern United States. Bull. Brooklyn Ent. Soc. 11, 1896, pp. 101-10\%.

1920. Bequaert, J. Bees and Wasps. Scientific Results of the Katmai Expedition of the National Geographic Society. Ohio Journ. Sci. 20, 1920, pp. 292-29\%.

1903-1905. du Buysson, $R$. Monographie des Guêpes ou Vespa. Ann. Soc. Ent. France 72, 1903, pp. 260-288; 73 (1904), 1905, pp. 485-556, 565-634.

1903. Carpenter, G. H. and Pack-Beresford, D. R. The Relationship of Vespa austriaca to Vespa rufa. Ent. Month. Mag. (2) 14, 1903, pp. 230-242, 1 pl.

1903. Evans, W. Vespa austriaca and V. rufa in Scotland. Ent. Month. Mag. (2) 14, 1903, pp. 299, 300.

1908. Fletcher, J. Vespa borealis an Inquiline? Ann. Ent. Soc. Amer. 1, 1908, p. 30; Psyche 15, 19n8, p. 16.

1903. Janet, Ch. Observations sur les Guêpes. Paris, C. Naud. 1903.

1878. Kristof, L. J. Ueber einheimische, geselliglebende Wespen und ihren Nestbau. Mitt. Naturw. Ver. Steiermark, 1878, p. 38.

1896. Marchal, P. La Reproduction et l'Evolution des Guêpes Sociales. Arch. Zool. Expér. et Gén. (3) 4, 1896, pp. 1-100, 6 figs. 
1864. Morawitz, F. Ueber Vespa austriaca Panz. und drei neue Bienen. Bull. Soc. Imp. Nat. Moscow 37, 1864, pp. 439449.

1859. Ormerod, E. L. Contributions to the Natural History of the British Vespidæ. The Zoologist 1\%, 1859, pp. 66416655 .

1910. Pérez, J. Notes sur les Vespides. Actes Soc. Linn. Bordeaux 44, 1910, pp. 1-20.

1898. Robson, J. E. Vespa austriaca, a Cuckoo-Wasp. Sciencè Gossip (N. S.) 5, 1898, pp. 69-73.

1903. Saunders, $E$. On the Relationship of Aculeate Inquilines and their Hosts. Ent. Month. Mag. (2) 14, 1903, pp. $272-274$.

1881. Schmiedeknecht, $O$. Ueber einige deutsche Vespa-Arten. Ent. Nachricht. 7, 1881, pp. 313-318.

1879. von Siebold, C. Th. E. Beiträge zur Parthenogenesis der Arthropoden. Engelmann, Leipzig, $18 \% 1$.

1899. Staden, F. W. L. Bombi in Captivity and Habits of Psithyrus. Ent. Month. Mag. 35, 1899, pp. 230-234.

1912. Sladen, F. W. L. The Humble-Bee, its Life-History and How to Domesticate it. Macmillan \& Co., London, 1912.

1918. Sladen, F. W. L. The Genus Vespa in Canada. Ottawa Naturalist 32, 1918, pp. 71-72.

1860. Stone, S. Facts connected with the History of a Wasp's Nest. Trans. Ent. Soc. London (2) 6, 1860, pp. 86-8\%.

1916. Viereck, $H$. Guide to the Insects of Connecticut. Part III. The Hymenoptera, or Wasp-like Insects of Connecticut. Bull. No. 22, State Geol. and Nat. Hist. Survey of Connecticut. 1916.

1919. Wheeler, W. M. The Parasitic Aculeata, a Study in Evolution. Proc. Amer. Phil Soc. 58, 1919, pp. 1-40. 


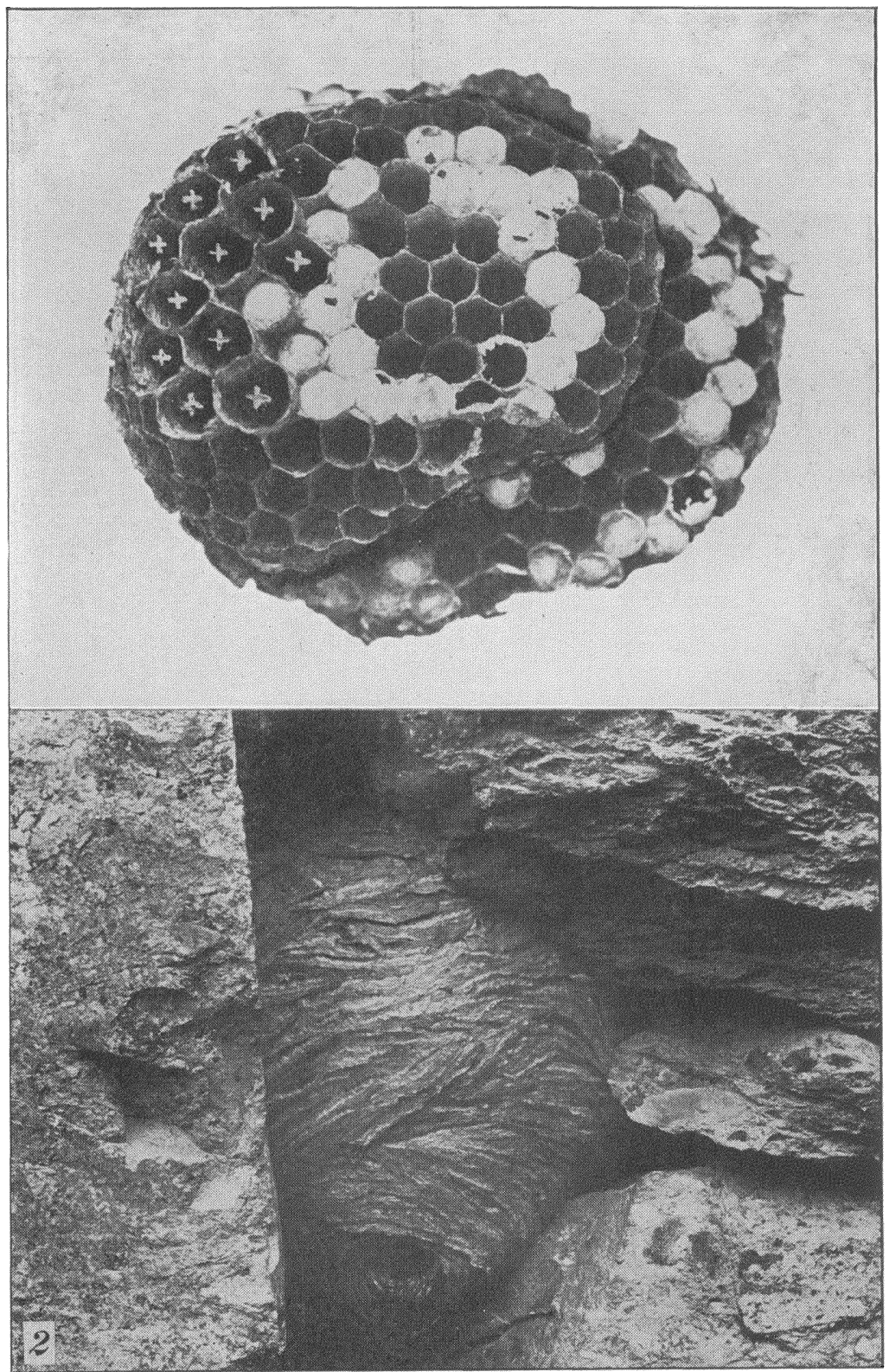

Wheeler \& Taylor - Vespa diabolica

Fig. 1. Combs from nest of Vespa diabolica taken by the senior author at Colebrook, Conn. The white croses at the left mark the large cells occupied by the larvæ of the parasite, Vespa arctica. Natural size.

Fig. 2. Typical nest of Vespa diabolica. about $2 / 5$ natural size. 




Fig. 3. Nest built by workers of Vespa diabolica. Natural size. 

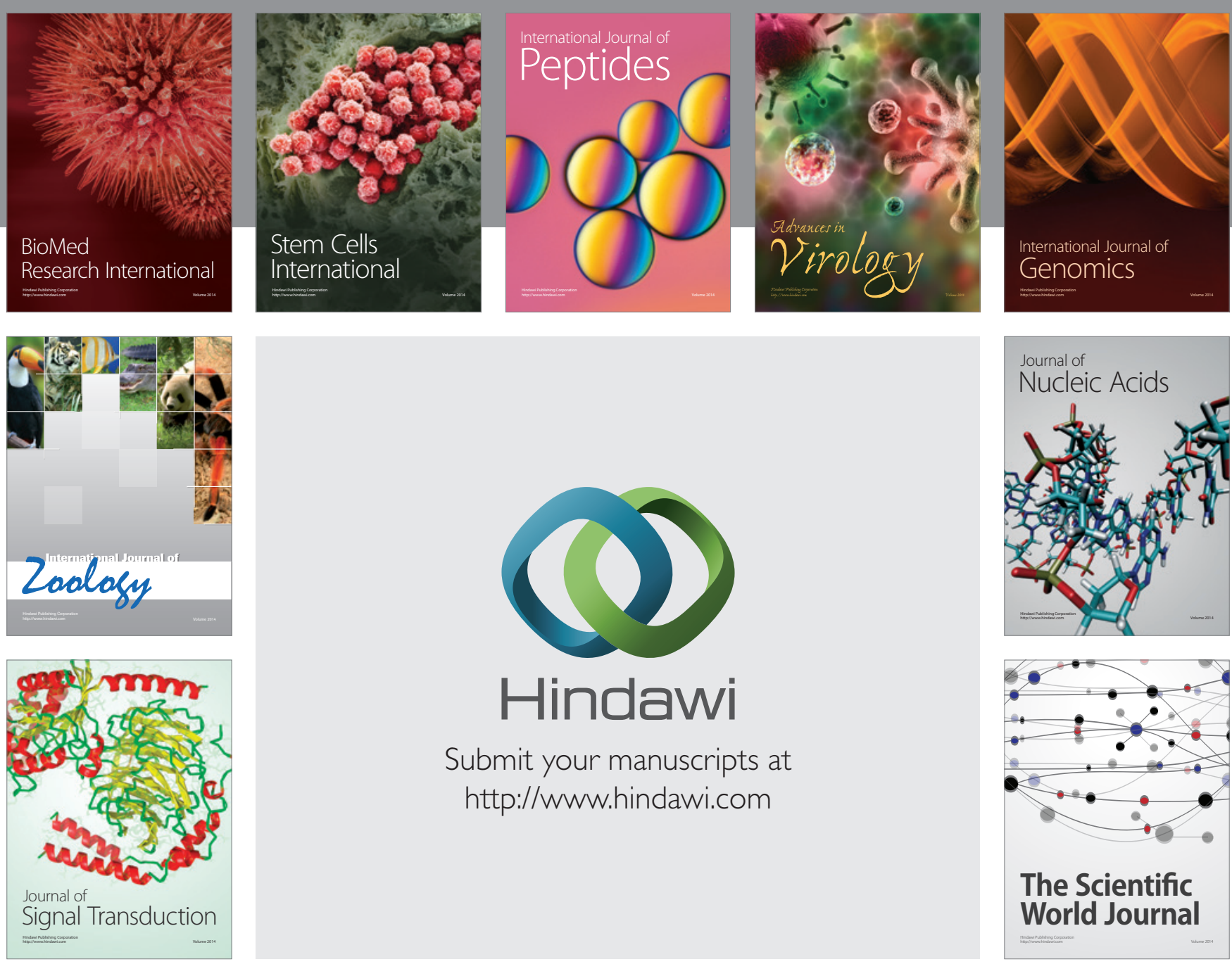

Submit your manuscripts at

http://www.hindawi.com
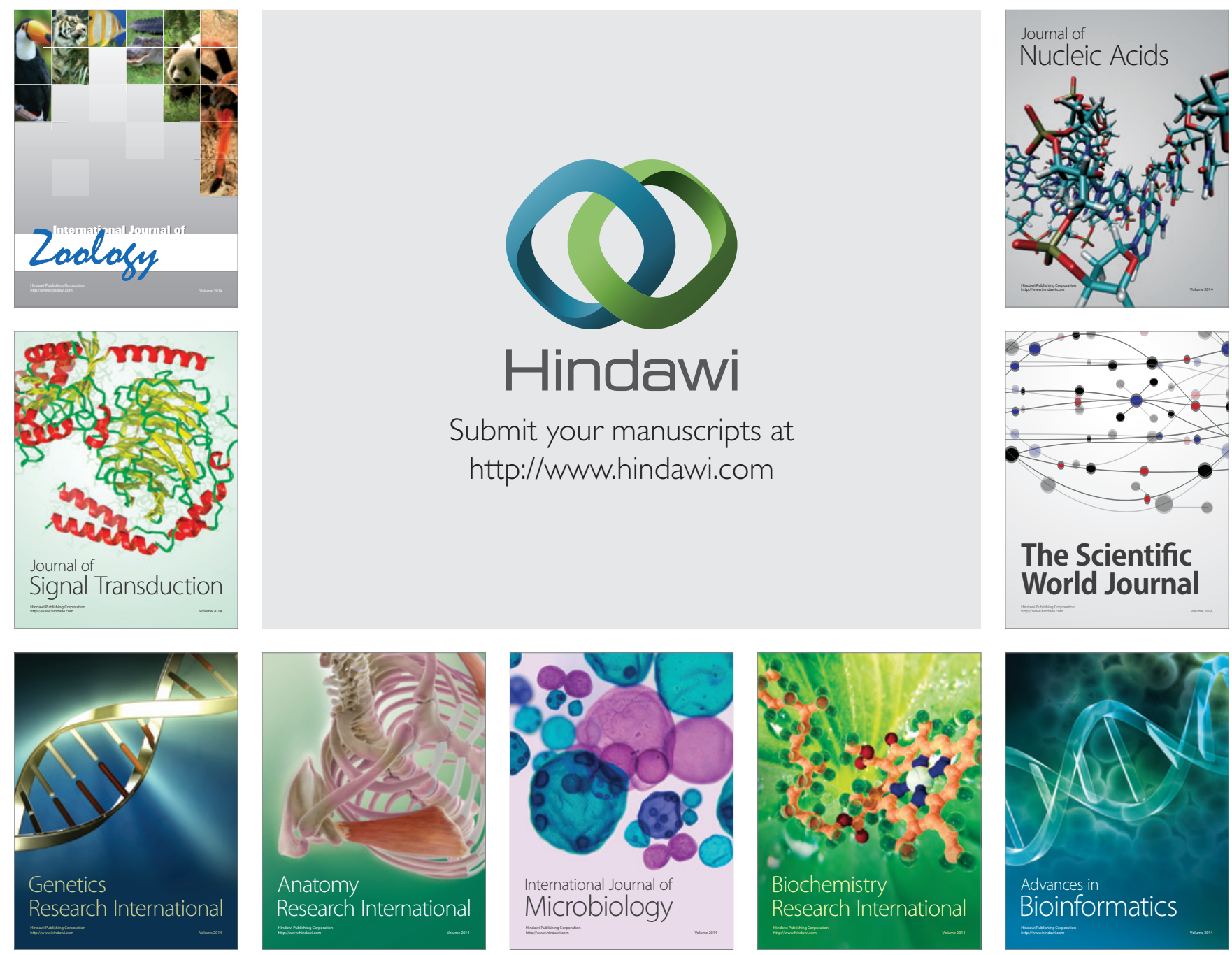

The Scientific World Journal
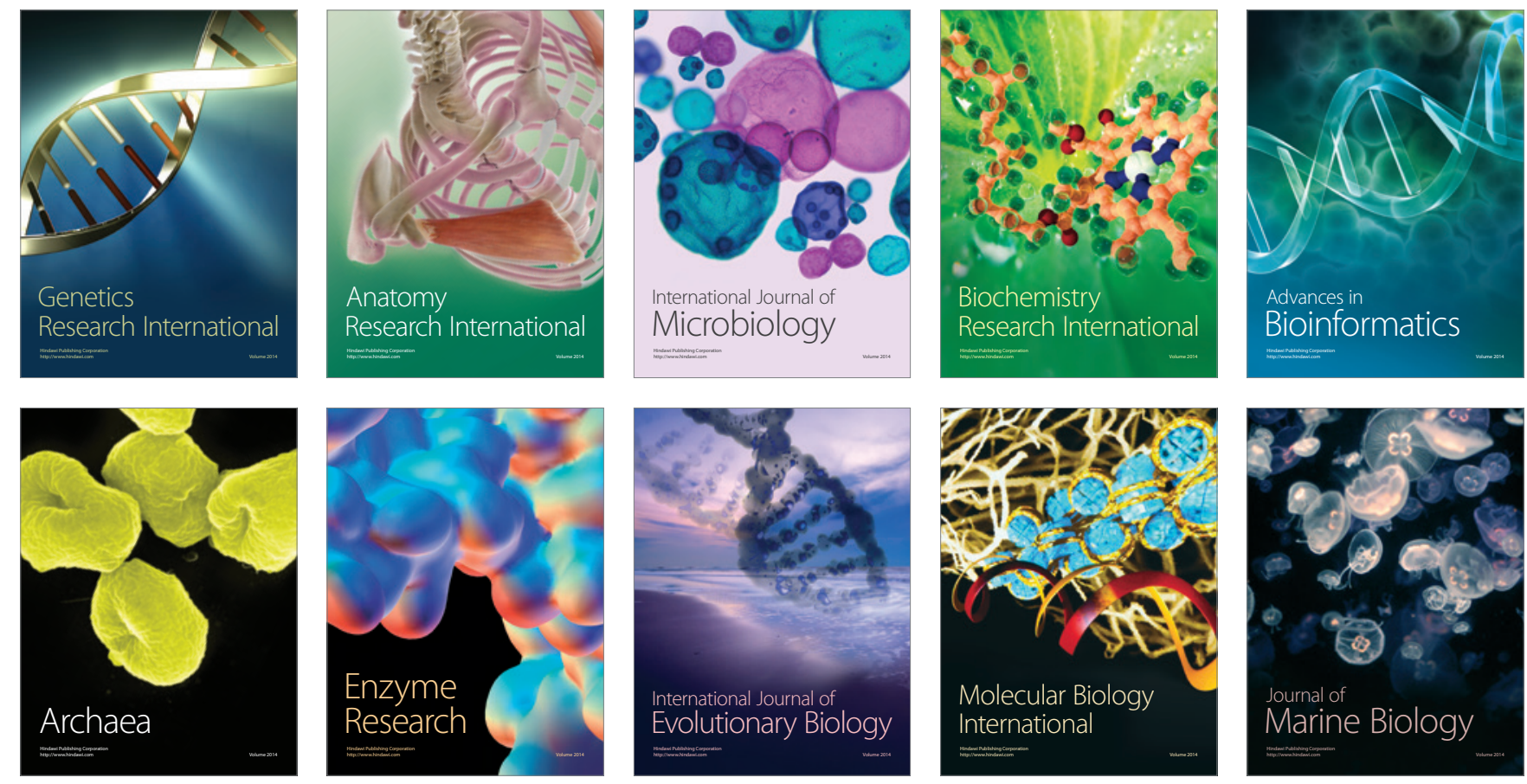